\title{
Effectiveness of the GAEC cross compliance standard Rational management of set aside (weed control through mowing) in assuring a minimum level of habitats maintenance
}

\author{
Marcello Raglione, ${ }^{1}$ Paolo Lorenzoni, ${ }^{1}$ Angelo Bonifazi, ${ }^{1}$ Roberto Nannelli,, Elena Gagnarli, \\ Paolo Bazzoffi, ${ }^{2}$ Roberta Gentile ${ }^{3}$ \\ ${ }^{1}$ Agricultural Research Council, CRA-APC Research Unit for Agropastoral Systems of the Central \\ Apennine, Rieti; ${ }^{2}$ Agricultural Research Council, CRA-ABP Research Centre for Agrobiology and \\ Pedology, Florence; ${ }^{3}$ Research Fellow, CRA-ABP Research Centre for Agrobiology and Pedology, \\ Florence, Italy
}

\begin{abstract}
The cross compliance standard Rational management of set aside (weeds control through mowing) regards sowable lands subject to the withdrawal from production (set-aside) or voluntarily withdrawn from the production. The aim of this standard is: i) to ensure a minimum level of maintenance of habitats; ii) to allow the maintenance of the productive potential and fertility of the soil; iii) to prevent the uncontrolled spread of weeds. Experimental data demonstrated that rational management of set aside according to GAEC standard 4.2 is very effective in increasing soil quality and stabilizing the edaphic animal community in terms of biodiversity. On the contrary minor improvement are made by the standard in the inland areas and high hills and mountain areas, where long crop rotations are adopted and soils are mainly used for long lasting natural or artificial meadow. The rule appears to be ineffective and even not suitable to prevent the spread of weeds, as the only one mowing or mulching ${ }^{1}$ of the natural vegetation, made mandatory by the standard, does not prevent the spreading of unwanted seeds to neighbouring cultivated fields. According to many authors, to leave a land uncultivated for a long period of time is not a good agricultural practice.
\end{abstract}

Correspondence: Marcello Raglione, Agricultural Research Council, CRAAPC Research Unit for Agropastoral Systems of the Central Apennine, via Casette 1, 02100 Rieti, Italy.

Tel. +39.0746 .256125 - Fax: +39.0746 .256129 .

E-mail address: marcello.raglione@entecra.it

Key words: GAEC, cross compliance, set aside, mowing, habitats maintenance.

Received for publication: 29 April 2011

Accepted for publication: 2 May 2011

() Copyright M. Raglione et al., 2011

Under no circumstances figures can be used without prior written consent of the copyright owner.

Licensee PAGEPress, Italy

Italian Journal of Agronomy 2011; 6(s1):e13

doi:10.4081/ija.2011.6.s1.e13

This work is licensed under a Creative Commons Attribution NonCommercial 3.0 License (CC BY-NC 3.0).
Natural vegetation cover which persists for a long period during the year is detrimental to the subsequent crop, because of the abundant seed production and consequent spread of weeds. At least two or three cuttings per year are needed to effectively reduce the spread of weeds, particularly in the presence of perennial species. Moreover, in order to avoid the spread of a single biological group of weeds, it is necessary to use different types of mechanical work in the course the year. Furthermore, the cutting period should be carefully chosen. Another suggested weed control practice is the use of doses of systemic foliar-absorption herbicides lower than the minimum quantity recommended and approved. In fact, in set aside land it is not necessary to completely dry out weeds, but it is sufficient to control the plant development in order to prevent the production of seeds. Cover crops and green mulching (mowing without residue removal) are other techniques that have been proposed in order to reduce the input of herbicides in no-tillage cultivation, without compromising weed control. Crop rotation is also a factor considered crucial to control weed populations. Studies on floristic evolution under Minimum Tillage or No-Tillage demonstrated that, to observe macroscopic changes, tillage should be reduced for 2-3 years at least. In an experiment conducted in Fagna (Florence) regarding the micro arthropods in the soil it was observed that significant differences exist between the abundance of animal groups. In particular, mulched set aside has a greater abundance of life forms than not mulched set aside, while the lowest abundance was observed in the ploughed soil. The increased abundance and richness of life forms observed in the mulched set aside plots, also evidenced by some diversity indices, can be explained by the increased amount of organic matter fragments left on the soil surface that ameliorate the edaphic microcosm.

\section{Introduction}

Legislation and aim of the study

GAECs (Standards of Good Agricultural and Environmental Condition) form part of the requirements under cross compliance and apply to anyone who receives payments under the Single Payment Scheme. GAECs set requirements for farmers in respect of soils, as well as maintaining a range of habitat and landscape features which are characteristic of the Italian countryside.

${ }^{1}$ Mulching: leaving the fragments of cut vegetation on the soil surface. 
The standard Rational management of Set aside (weed control through mowing) concerns the environmental objective to ensure a minimum level of maintenance and avoid the deterioration of habitats indicated in Annex IV of REG. EC 1782/03. This standard was introduced under Rule 4.2 by successive Mipaaf ${ }^{2}$ decrees on cross compliance from mid 2004 (Decree 1787/2004 et seq.) until the end of 2009. The Mipaaf Decree of December 2009, issued following the CAP Health Check, ${ }^{3}$ kept this standard (Standard 4.2) as part of Norm 4 Measures to protect land and habitat. The standard was made obligatory for all set asided surfaces.

The aim of this work, carried out in the context of the EFFICOND ${ }^{4}$ project, is to assess the effectiveness of standards in achieving the environmental objective of maintaining the habitat, through the collection of observations made in Italy by several authors in study cases.

\section{History and description of set aside}

Set aside land, which consists in a period of not cultivation, was adopted since the beginning of agriculture. The most diffused and famous form of set aside is certainly constituted by the Maggese practice, for the first time described in the Georgics by Virgil, in the first century B.C.

Maggese is a tilled set-aside more advanced than a simple land abandonment. In the rotation, some fields are excluded from production for a period of one year or more. These fields are ploughed 3-8 times in the period between late winter and November, to allow the soil to rejuvenate under the action of air, rain and soil fauna. In North Europe, since the eleventh century, the rotation scheme has evolved from two years to three years succession of crops. The same happened in the Mediterranean regions, starting from the nineteenth century. This change led to a sharp reduction in the maggese area. The main cause of the increasing reduction of areas devoted to maggese in the most advanced European countries, starting from the seventeenth and eighteenth centuries, was the introduction of forage crops in rotation.

Maggese disappeared from the countryside of Western Europe but remained in the Mediterranean area as an essential component of dry farming. The withdrawal of land for several years was an economic loss for farmers. For this reason, in modern agriculture, the maggese practice has been replaced by the cultivation of fodder plants or leguminous for green manure. Set-aside was introduced as a political measure by the European Union (EU) in 1988 to help reduce the large and costly surpluses produced in Europe under the guaranteed price system of the Common Agricultural Policy (CAP); and to deliver some environmental benefits following considerable damage to agricultural ecosystems and wildlife as a result of the intensification of agriculture. Set-aside became compulsory in 1992 . It was originally set at $15 \%$ and reduced to $10 \%$ in 1996. Following the introduction of decoupled payments in 2005 , farmers who had historically claimed set-aside were awarded a number of set aside entitlements equivalent to the area they had previously setasided. In order to receive payment on these set-aside entitlements, an equivalent number of hectares had to be removed from agricultural production.

\footnotetext{
${ }^{2}$ Ministry of Agricultural, Food and Forestry Policies.

${ }^{3}$ On 20 November 2008 the EU agriculture ministers reached a political agreement on the Health Check of the Common Agricultural Policy (CAP). The Health check introduced a number of changes to the EU rules for the Single Payment Scheme (SPS) and other direct aid schemes.

${ }^{4}$ EFFICOND $(E F F=$ Effectiveness of environmental standards, COND $=$ Cross compliance $)$ is a CRA (Agricultural Research Council) project started in 2009 to meet the specific need of NRN (National Rural Network) to monitor and evaluate the effectiveness of environmental protection actions mandated by the CAP to national agricultural policy and implemented by the Regional Rural Development Plans (RDP). The main project objectives are the evaluation of GAEC standards implemented under cross compliance and the development of agrienvironmental indicators for nation-wide scenario analysis. The EFFICOND project involves 10 operational units with experimental fields located throughout the country.
}

On 16 July 2007 the European Commission (EC) announced its intention to publish a proposal to reduce the set-aside requirement to $0 \%$ in 2008 , and the proposal was adopted on 26 September 2007. This was to help mitigate current shortage in the EU cereals market and increase cereals supply to the market and therefore reduce prices following two consecutive lower EU harvests.

The EC agreed in November 2008 to abolish set-aside completely through the CAP Health Check. Further EC decrees (1782/03, 1698/05, 1975/06, 1234/07, 479/08, 555/08, 73/09, 491/09, 1120/09, 1122/09) were adopted by Italy through the successive Mipaaf Decree on Cross compliance. This legislation includes set aside among the Good Agricultural and Environmental Condition (GAEC) Standards under the single payment scheme.

\section{The environmental value of set aside}

Although it was not its goal, set aside has produced accidentally significant environmental benefits.

A vital agricultural environment requires a minimum size of land that are excluded from intensive cultivation (retired) and which are managed in ways that produce positive environmental effects. It is widely reported that set aside land are important environments for food and reproduction of many wild species, in particular for birds of farming areas whose populations are in serious decline across Europe (Evans et al. 1997). In reproductive period, fallow land are home to relatively high density of bird species compared to sowable land (Henderson et al., 2000). Gillings et al. (2010), in a study spanning a wide range of arable and mixed farming systems, showed that during both winter and the breeding season, set-aside held consistently higher densities of many farmland bird species than arable crops.

Van Buskirk and Willi (2004) evaluated the biodiversity benefits of set-aside land in North America and Europe with a meta-analysis approach. They demonstrated that set-aside, in general, has a positive effect on all aspects of the biodiversity of agricultural habitats. That is: higher numbers of birds, insects, spiders and plants than cultivated land. Furthermore, they found a positive relationships between biodiversity and age and area of set-aside land. Based on these results, they conclude that agro-environmental policies are effective and recommend that greater amounts of land should be set aside regionally in Europe and North America to maximize biodiversity benefits.

The non-cultivation of set aside land leads to a reduction of agrochemical input resulting in the reduction of pollution caused by pesticides and fertilizers. When set aside land are located along water courses, the presence of fertilizers and pesticides in the water can be significantly reduced (Silcock and Lovegrove, 2007). In the Po valley, that is affected by significant water pollution problems caused by nitrates and phosphates, set aside can play an important role to achieve the objectives of the WFD.

As demonstrated by Bazzoffi (2011) set-aside has helped reduce soil erosion. In many cases, set-aside fields are located in areas where soil is more subject to erosion and is less productive. Set aside can also play an important role in mitigating the effects of climate change by providing a habitat for wildlife within the cultivated areas. Wild species will need more than before to move in search for conditions appropriate to their ecology. This is particularly important in Italy, where more than half of land is cultivated. Then, a successful strategy of protection of wildlife, according to EU Green Paper on climate change, must ensure that wildlife can move through the cultivated areas. This will be possible if within cultivated areas suitable habitats, as set aside lands, are present.

Regarding maggese, no scientific evidences about the improvement of soil properties are reported in the literature, although tradition has always attributed, since the most remote times, a positive effect of this practice. On the contrary, there are many publications on the manage- 
ment of set-aside related to wildfires prevention.

Pardini et al. (1994), ) published an interesting work on the influence of grazing on strips of land devoted to forest firebreak lines. The research demonstrated that herbaceous vegetation is better utilized by sheep than cattle, with a more efficient weed control. Another interesting result of this study was the increase in grass cover observed on firebreak lines under forest, when grazing was allowed on these set aside areas. In fact, cattle manure quadrupled the amount of clover seed present on forest soil.

In conclusion, the sheep used the seeds in summer and improved turf in open spaces, while cattle ensured a better seed spread throughout the forest and better control of invasive shrubs. The authors concluded that for a more balanced management of forest-pastoral systems a mixed sheep-cattle grazing is recommended. Paradisi et al. (1997), studied different management systems of set-aside. According to the authors, soil abandonment during the whole set-aside period is not a good practice. The presence of natural and well established vegetation cover during many months is detrimental to the subsequent crop because of the high spread of weeds. On the contrary the study demonstrated that mulching: i) determined the disappearance of some weeds species (E. telmateja); ii) reduced the presence of some invasive species (C. inthybus); iii) increased the presence of other weeds (Amaranthus spp, C. canadensis and E. crus-galli) (Figure 1). In conclusion, the study showed that mulching, without the addition of other treatments, is able to keep soil free from weeds for quite long periods of time.

Two or three cuts per year are able to control perennial weed species but are less effective against fast-growing ones. Montemurro et al. (1997) performed a research on set aside management in Southern Italy.

In this experiment a comparison among different agronomic practices has been carried out (no-tillage, mulching, rotary harrowing, ploughing, ploughing + rotary harrowing). Working times were also measured. Results showed an increase of infestation in the following circumstances: i) when mowing is done later than the optimum date; ii) when no-tillage is applied; iii) when a single mowing is carried out late in May.

Covarelli (1997), reported the effects of natural flora management by comparing 11 theses including early mulching, late mulching, double mulching, harrowing and herbicide treatments. The results for the first year of testing showed that:

on set-aside land weeds consisted mainly of Lolium multiflorum;

early mulching in May stimulated the growth of new sprouts from basal buds. Furthermore, one month after mulching high values of surface vegetative cover and biomass per unit area were observed;

- the efficiency of weeds control through harrowing was similar to mulching, with the addition that it was able to prevent the growth of new sprouts;

after chemical weeding, only a few plants were able to sprout new shoots.

- in all plots where weeding was not applied the vegetation cover by Lolium multiflorum was very high in mid-June;

- it was clearly observed that a late weeding (over mid-June) is not able to control the increase of weed spreading (Figure 2);

all management methods determined a reduction of vegetation cover, in a different way depending on thesis;

- mulching, compared to harrowing, increased seed production, although not statistically significant.

Covarelli et al. (1993) analyzed the advantages and disadvantages of the presence of natural vegetation cover.

Disadvantages:

- high quantity of seeds production with consequent increase of potential soil infestation;

particularly hospitable environment for pests, harmful to subsequent cultivated plants;

obstacle to transplanting or to seedbed preparation for next crop;

removal of nutrients and water from the soil.

Advantages:

- decrease of runoff and erosion;

reduction of nitrate leaching;

refuge for wild species and ideal habitat for the development of many beneficial insects;

increase in soil organic matter content due to root residues and possible burial of mulch residues.

The same authors observed that uncontrolled weed plants on unmanaged set aside can reach a very high development (in some experiments conducted in Perugia the dry biomass of plants on a setaside was between 4 and $9 \mathrm{Mg} \mathrm{ha}^{-1}$ year-1). Consequently, weed control through tillage, mulching, herbicides and cover crops is needed. Early tillage (by mid May) is not sufficient to prevent the development of late thermophilic weed species (Portulaca oleracea, Echinocloa cruss-galli,

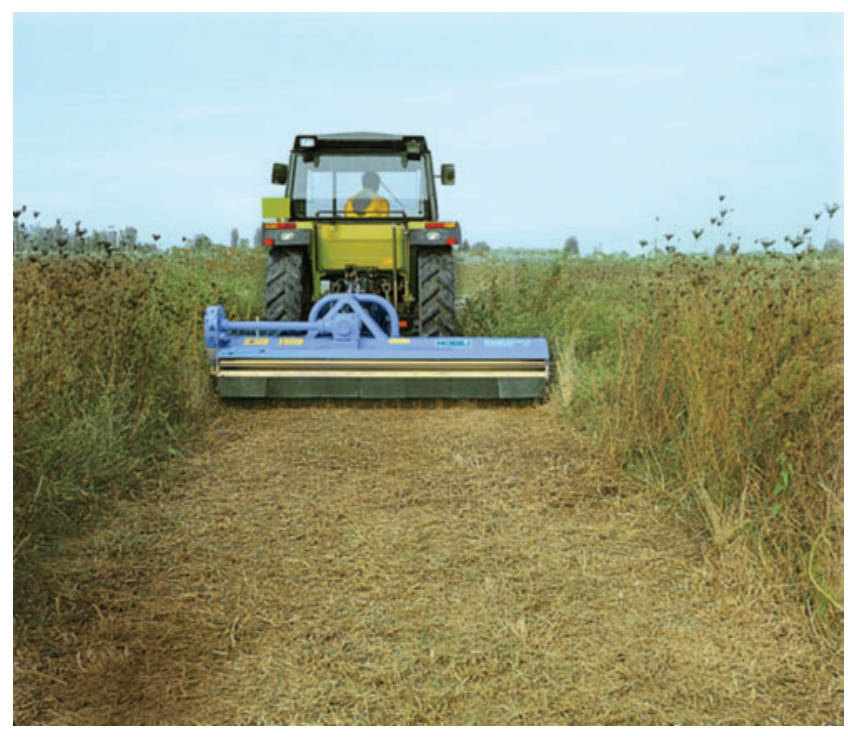

Figure 1. Mulcing on set aside land, in order to comply with the cross compliance standard (Courtesy of Nobili S.p.A. agricultural machinery factory).

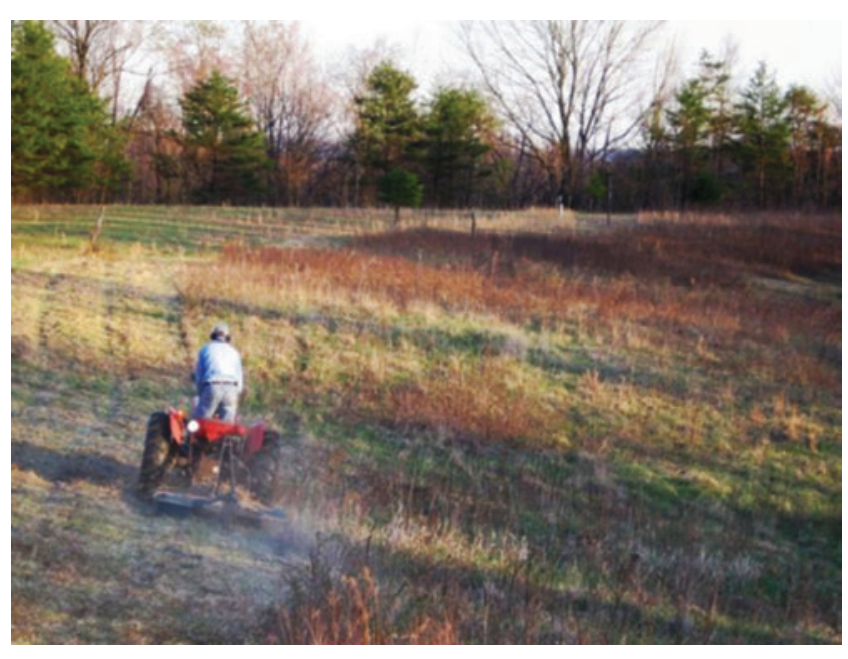

Figure 2. Late mowing on set aside is not able to control the increase of weed spreading. In this example brown plants reveal that dissemination of weeds occurred massively. 
Solanum nigrum and Amaranthus troflexus). For this reason, tillage must be repeated at the end of June or in July. It must also be considered that superficial tillage often exerts a limited effect in the presence of very well developed weeds.

Tillage often brings weed seeds to the soil surface. In particular chisel ploughing is not able to devitalize well established weeds, especially tillered graminaceous and taproot plants. Tillage also disturbs wildlife and hinders its settlement during the optimal time for ploughing that coincides with the nesting period. Mulching leaves in place fragmented plant residues that contribute to hinder the emergence of weeds. Mulching and mowing of weeds should be performed before the seed spreading phase.

These two operations must be repeated several times in the year to control both the species that emerge after cutting and perennial or tillered cespitosa species, which are stimulated by mowing to sprout new shoots.

Mulching and mowing exert some beneficial effects on habitat: they devitalize weed species that are not able to develop new shoots, do not disturb soil and therefore do not increase erosion. They are rapid and less expensive operations than tillage. However, they constitute a danger to wildlife and have a reduced effectiveness against certain plant species characterized by a tillered and very close to soil canopy. The chemical weeding can be used to control weeds in set aside land; the quantity of herbicides can be much smaller than the one applied on cultivated land. It presents moreover some advantages with reference to other management practices:

- it avoids the production of weed seeds;

- it keeps a vegetative cover on the soil surface that exerts a valid protection against soil erosion and weed growth, and at the same time, guarantees the refuge function for wildlife;

- it allows the direct sowing of subsequent crop in the rotation setaside scheme;

- it is economically competitive with respect to other weeding methods;

- it is the only intervention that allows the total weeding of multiyear species.

The authors concluded that to keep under control the natural vegetation at least two or three treatments per year are required. Furthermore, to prevent the spread of a single group of weeds it is necessary to vary the different mechanical treatments (mowing and mulching) during the year.

Berti and Sattin (1993) discussed the effects of minimum tillage and no-tillage on the development and management of weeds on set aside land; according to the authors:

- minimum tillage favors neophyte and emicriptophyte species and annual species that produce small and long-living seed. On the contrary many dicotyledonous species result disadvantaged by minimum tillage;

- the greater organic matter content and undecomposed residues of soil surface layers increase the adsorption of herbicides. Consequently, a decrease of herbicide effectiveness occurs,

minimum tillage and no-tillage lead to an increase of soil moisture in the surface layer due to increased soil microporosity and soil moisture content at field capacity (Ball and 0' Sullivan, 1982; Eckert, 1984; Pagliai et al., 2004);

- soils partially or totally covered by crop residues are heated more slowly during the spring period (Cavazza et al., 1986); this determines a longer period of time for plant growth and lowers the growth velocity of both crop and weeds;

- in general, the integration of different interventions and strategies is needed to effectively control weeds: use of crops competitiveness as limiting factor for weeds growth, precise use of herbicides, rotations and use of different tillage instruments;

- changes in the composition of the natural flora, due to natural caus- es, are important in controlling weeds. A change in the flora composition due to annual or seasonal fluctuation is reversible. On the contrary a change induced by a succession process of different species is unidirectional, continuous and non-seasonal (Swanton et al., 1993);

- tillage is one of the most effective tool to stop in the early stages the changes of flora due to the succession process. So, a reduction or elimination of tillage must be balanced by the use of herbicides and by effective rotations in order to influencing the flora evolution.

The rational management of set-aside areas, in order to avoid weeds spreading, becomes essential especially for adjacent areas cultivated through minimum or no tillage. Rodriguez (1993) notes that species that grow freely in the absence of crop have a greater dissemination capacity with respect to cultivated areas. This behavior is essentially due to no competition and reduced noise in set aside land. Purvis (1990) found that the allelopathic action exerted by the residues of some species reduced weed emergency. For example, rye residues on soil surface are able to prevent Portulaca oleracea growth and severely limit Setaria viridis and Amaranthus retroflexus growth, too.

Some species are able to perform a biocidal activity. For example, Raphanus sativus var. oleiformis and Sinapis alba can limit the spread of the sugar beet nematode (Heterodera schactii). Others species have remarkable melliferous properties (Phacelia tanacetifolia) and others can provide food and protection to wildlife (ryegrass, white clover, sainfoin) (Agronomica, 1995). Appropriate practices to reduce the spread of weeds from set-aside lands are the timely elimination of vegetation cover by mechanical and chemical actions. Elimination of annual species, such as vetch, crimson clover, phacelia, mustard, can be efficiently done through a unique intervention of mulching done shortly before the next crop sowing. For species with high regrowth capacity, such as ryegrass, white and purple clover and radish, it is advisable to plow soil by using mouldboard or apply a total non-residual herbicide.

Natural vegetation and its management on set aside lands play an important role on the biological soil quality. This issue is quite complex as it depends on the combination of the physical, chemical and biological properties. Several Authors proposed new methods for soil-quality assessment based on soil mesofauna communities, particularly soil arthropods. These indices take into account the whole soil microarthropod community, following the concept that the higher the soil quality is, the higher will be the number of micro-Arthropod groups well adapted to the soil habitats (Parisi et al., 2005).

Several organisms such Collembola, Acari and Carabidae (Coleoptera) are identified as indicators of different management farming systems.

The Biological Soil Quality, BSQ-arthropods (BSQ ${ }_{\mathrm{ar}}$ ) index (Parisi, 2001; Parisi et al., 2005) has been recently proposed as an integrated approach. $\mathrm{BSQ}_{\mathrm{ar}}$ index uses the biological form approach to separate the organisms into morphological classes according to their different levels of adaptation to a soil environment. To date, few applications of BSQar have been published in Italy (Parisi, 2001; Gardi et al., 2002; D’Avino, 2002; Parisi et al., 2005; Biaggini, 2005; Biaggini et al., 2007; Ferrazzi et al., 2007; Menta et al., 2008; Tabaglio et al., 2009; Aspetti et al., 2010; Mazzoncini et al., 2010).

\section{Experiments conducted in the framework of the EFFI- COND project}

To evaluate the effectiveness of the GAEC standard two experiment have been started (currently still in progress) in the CRA-APC experimental farm of Colle S. Pastore (province of Rieti) and in the CRA-ABP experimental farm of Fagna, Scarperia (province of Florence).

The Colle S. Pastore test was focused on the evolution of the most significant soil parameters (organic carbon content and soil bulk density) in order to evaluate the effect of set aside on soil in comparison with other soil uses. 
The Fagna experiment was focused on the evaluation of the environmental effectiveness of set aside, applied according to GAEC rules, on the Biological Soil Quality (BSQar).

\section{Materials and Methods}

\section{CRA-APC Experimental farm of Colle S. Pastore}

A test was carried out in two different soils of Colle S. Pastore farm, belonging to the Research Unit for Agropastoral Systems of the Central Apennine (Figure 3).

The two soils, characterized by different physical and chemical properties and represented by pedon Piedifiume (PF) and Casabianca (CB) are classified as Typic Eutrudept and Vertic Eutrudept respectively (Soil Survey Staff, 2003). Their main physico-chemical characteristic are shown in Tables 1 and 2. The test, started in 2009, consists in a four years succession of common wheat (Triticum aestivum), set aside, Vicia faba var. minor, common wheat, in eight plots (four for each type of soil, numbered from 4 to 7 ) of about 1 hectare each, according to scheme reported in Table 3, in order to evaluate the effects on soil of annual set aside. A minimum tillage at depth of $10-12 \mathrm{~cm}$ by a disk harrow was executed in order to bury cultivation residues of wheat (stubble) and Vicia faba var. minor (green manure), while the natural vegetation of uncultivated plot was mulched two times per year, in the months of April and June. A sampling of the soil, at depths of $0-10 \mathrm{~cm}$, was carried out in each plot at the beginning of the test in 2009, and on the second and third agricultural year after the harvest of wheat.The soil samples were air dried and sieved through a $2 \mathrm{~mm}$ mesh. Laboratory analysis were performed according to the Italian standard procedure of soil chemical analysis (Mipaaf, 2000). In particular organic carbon content (OC) was determined by the Walkley-Black method while oven dry bulk density was determined after sampling an undisturbed soil core with the method of steel cylinder (method II.1.3.1, Mipaaf, 1997).

\section{CRA-ABP experimental farm of Fagna, Scarperia}

From autumn 2009 to spring 2010, the quality of soil biology was investigated on three different types of soil management in the Fagna study area. The treatments of soil considered were as follows: i) abandoned soil (spontaneous and not grazed vegetation since 2007) where no application of the GAEC rule was carried out; ii) natural grass with annual mowing; iii) ploughing with green manure followed by set aside (in accordance with the standard). In each field, five soil cores (150 cc of soil) were collected; then, arthropods were extracted from each soil sample using Berlese-Tullgren funnels. Animals were identified, counted and classified into different taxa at the order level. The microarthropod community was evaluated by applying the $\mathrm{BSQ}_{\mathrm{ar}}$ index and other biodiversity indices (Margalef, 1994; Shannon and Weaver, 1949; Simpson, 1949). Each form was eco-morphologically scored (EMI) ranging from 1 to 20 , on the basis of its adaptation level. The sum of EMI's gave the global value of $\mathrm{BSQ}_{\mathrm{ar}}$ index.

\section{Results and Discussion}

\section{CRA-APC Experimental farm of Colle S. Pastore}

The particle size analysis, carried out on soil samples collected (0-10 $\mathrm{cm}$ ) at the beginning of the test in all experimental fields, confirmed the relative textural homogeneity inside each type of soil (Table 4). The four plots relative to pedon Piedifiume are loam with a clay content which varies from $16.0 \%$ to $17.8 \%$, while the plots of Casabianca soil are
Table 1. Main physical and chemical characteristics of Piedifiume soil.

\begin{tabular}{|c|c|c|c|c|}
\hline $\begin{array}{l}\text { Pedon Piedifiume } \\
\text { Horizon } \\
\text { Depth (cm) }\end{array}$ & $\underset{0-45 / 50}{\mathrm{Ap}}$ & $\begin{array}{c}\mathrm{Bw} \\
45 / 50-90\end{array}$ & $\begin{array}{c}\mathrm{Cg} 1 \\
90-135\end{array}$ & $\begin{array}{c}\text { Cg2 } \\
135-205+\end{array}$ \\
\hline \multicolumn{5}{|l|}{ Physical analysis } \\
\hline $\begin{array}{l}\text { Particle size } \\
\text { Coarse + medium sand } \\
(2000 \div 250 \mu \mathrm{m})(\%)\end{array}$ & 1.0 & 0.5 & 0.6 & 3.0 \\
\hline $\begin{array}{l}\text { Fine + very fine sand } \\
(250 \div 50 \mu \mathrm{m})(\%)\end{array}$ & 28.1 & 28.9 & 36.0 & 62.3 \\
\hline Total sand (\%) & 29.1 & 29.4 & 36.6 & 65.3 \\
\hline Coarse silt $(50 \div 20 \mu \mathrm{m})(\%)$ & 27.6 & 27.7 & 25.7 & 22.2 \\
\hline Fine silt $(20 \div 2 \mu \mathrm{m})(\%)$ & 27.7 & 23.8 & 21.1 & 7.3 \\
\hline Total silt (\%) & 55.3 & 51.5 & 46.8 & 29.5 \\
\hline Clay $(\%)$ & 15.6 & 19.1 & 16.6 & 5.2 \\
\hline \multicolumn{5}{|l|}{ Chemical analysis } \\
\hline $\mathrm{pH}\left(\mathrm{H}_{2} \mathrm{O}\right)$ & 8.1 & 8.3 & 8.4 & 8.6 \\
\hline $\mathrm{pH}(\mathrm{KCl})$ & 7.2 & 7.3 & 7.4 & 7.7 \\
\hline Total $\mathrm{CaCO}_{3}\left(\mathrm{~g} \mathrm{~kg}^{-1}\right)$ & 39 & 59 & 128 & 128 \\
\hline Active $\mathrm{CaCO}_{3}\left(\mathrm{~g} \mathrm{~kg}^{-1}\right)$ & 7 & 15 & 32 & 15 \\
\hline Total organic C $\left(\mathrm{g} \mathrm{kg}^{-1}\right)$ & 9.8 & 8.0 & 5.4 & 1.3 \\
\hline Organic matter $\left(\mathrm{g} \mathrm{kg}^{-1}\right)$ & 16.8 & 13.8 & 9.3 & 2.2 \\
\hline Total N (g kg-1) & 1.5 & nd & nd & nd \\
\hline $\mathrm{C} / \mathrm{N}$ & 7 & nd & nd & nd \\
\hline \multicolumn{5}{|l|}{ Exchangeable bases $\left(\mathrm{cmol}^{(+)} \mathrm{kg}^{-1}\right)$} \\
\hline $\mathrm{Ca}+\mathrm{Mg}^{\circ}$ & 17.1 & 14.8 & 12.7 & 4.5 \\
\hline $\mathrm{Na}$ & 0.46 & 0.33 & 0.26 & 0.36 \\
\hline $\mathrm{K}$ & 0.30 & 0.24 & 0.12 & 0.08 \\
\hline C.E.C. $\left(\mathrm{BaCl}_{2}\right)\left(\mathrm{cmol}(+) \mathrm{kg}^{-1}\right)$ & 17.9 & 15.4 & 13.1 & 4.9 \\
\hline Base saturation (\%) & 100 & 100 & 100 & 100 \\
\hline Available $\mathrm{P}$ as $\mathrm{P}_{2} \mathrm{O}_{5}\left(\mathrm{mg} \mathrm{kg}^{-1}\right)$ & 30.1 & 10.5 & 4.5 & 7.4 \\
\hline
\end{tabular}

${ }^{\circ} \mathrm{Ca}+\mathrm{Mg}=$ C.E.C. $-\left(\mathrm{Na}^{+}+\mathrm{K}^{+}\right)$. nd, not determined.

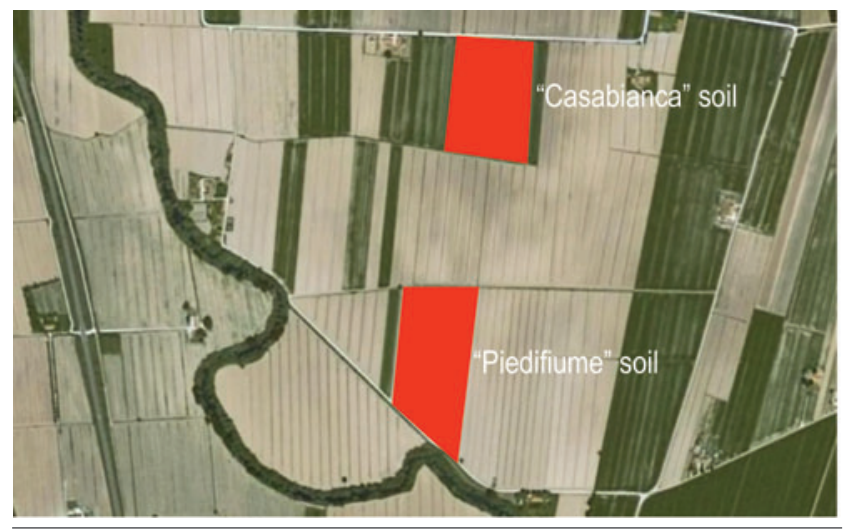

Figure 3. Experimental areas of CRA-APC (province of Rieti) represented by red colour (image by Google Earth).

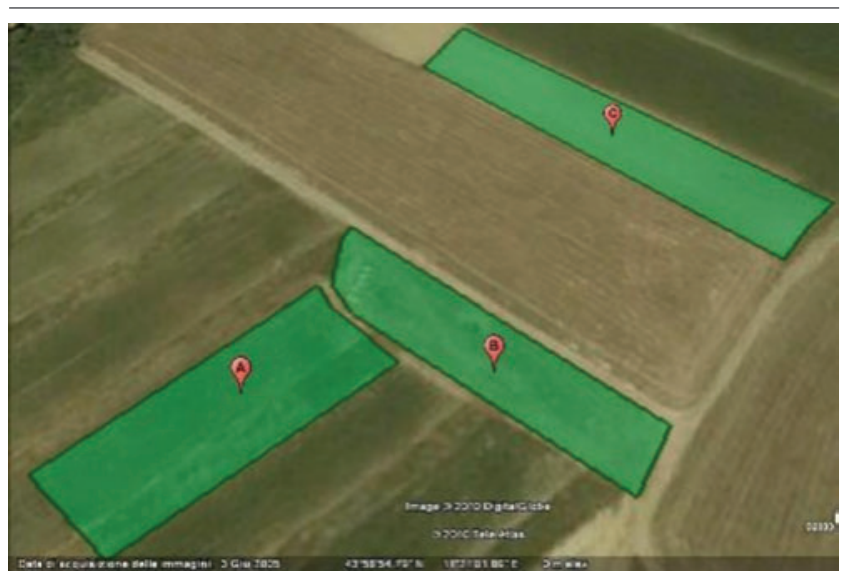

Figure 4. Fagna experimental areas (A, B, C) (in green), characterized by the biological class V (D'Avino, 2002) (image from Google Earth). 
mainly silty clay (only the plot CB 7 has a slightly lower clay content than the other $\mathrm{CB}$ plots). Also the values of $\mathrm{pH}$, one of the main chemical parameter, measured in both water and $\mathrm{KCl} 1 \mathrm{~N}$, indicated a good homogeneity among the four fields for each soil type (Table 5). The results of the change over the time of both organic carbon content and dry bulk density, in PF and CB soils, after a period of two agricultural years, are shown in Table 6 . The short period of time between the two observations makes it difficult and uncertain the interpretations of the collected data. From data it is possible to argue that only in the fields of Piedifiume and Casabianca (where the green manure was executed three months before soil sampling on August 2010), a light increase in organic carbon content and a decrease in bulk density occurred. This

Table 2. Main physical and chemical characteristics of Casabianca soil.

\begin{tabular}{|c|c|c|c|c|c|c|}
\hline $\begin{array}{l}\text { Pedon Casabianca } \\
\text { Horizon } \\
\text { Depth (cm) }\end{array}$ & $\underset{0-35 / 40}{\text { Ap }}$ & $\begin{array}{c}\text { Bw } \\
35 / 40-60\end{array}$ & $\begin{array}{c}\mathrm{Bg} \\
60-80\end{array}$ & $\begin{array}{c}\mathrm{Cg} 1 \\
80-110\end{array}$ & $\begin{array}{c}\text { Cg2 } \\
110-170\end{array}$ & $\begin{array}{c}\text { Cg3 } \\
170-185+\end{array}$ \\
\hline \multicolumn{7}{|l|}{ Physical analysis } \\
\hline \multicolumn{7}{|l|}{ Particle size } \\
\hline Coarse + medium sand $(2000 \div 250 \mu \mathrm{m})(\%)$ & 1.1 & 0.3 & 0.5 & 1.0 & 1.1 & 3.0 \\
\hline Fine + very fine sand $(250 \div 50 \mu \mathrm{m})(\%)$ & 7.3 & 2.3 & 3.0 & 7.2 & 3.7 & 76.9 \\
\hline Total sand (\%) & 8.4 & 2.6 & 3.5 & 8.2 & 4.8 & 79.9 \\
\hline Coarse silt $(50 \div 20 \mu \mathrm{m})(\%)$ & 5.6 & 0.4 & 2.3 & 10.0 & 7.4 & 7.3 \\
\hline Fine silt $(20 \div 2 \mu \mathrm{m})(\%)$ & 36.0 & 40.9 & 40.9 & 39.0 & 46.5 & 5.8 \\
\hline Total silt (\%) & 41.6 & 41.3 & 43.2 & 49.0 & 53.9 & 13.1 \\
\hline Clay (\%) & 50.0 & 56.1 & 53.3 & 42.8 & 41.3 & 7.0 \\
\hline \multicolumn{7}{|l|}{ Chemical analysis } \\
\hline $\mathrm{pH}\left(\mathrm{H}_{2} \mathrm{O}\right)$ & 7.7 & 8.1 & 8.2 & 8.3 & 8.4 & nd \\
\hline $\mathrm{pH}(\mathrm{KCl})$ & 6.7 & 6.9 & 7.0 & 7.0 & 7.0 & nd \\
\hline Total $\mathrm{CaCO}_{3}\left(\mathrm{~g} \mathrm{~kg}^{-1}\right)$ & 123 & 115 & 180 & 161 & 161 & 132 \\
\hline Active $\mathrm{CaCO}_{3}\left(\mathrm{~g} \mathrm{~kg}^{-1}\right)$ & 60 & 77 & 109 & 92 & 94 & nd \\
\hline Total organic C $\left(\mathrm{g} \mathrm{kg}^{-1}\right)$ & 14.5 & 12.3 & 9.1 & 7.3 & 6.5 & nd \\
\hline Organic matter $\left(\mathrm{g} \mathrm{kg}^{-1}\right)$ & 24.9 & 21.2 & 15.6 & 12.6 & 11.2 & nd \\
\hline Total $N\left(\mathrm{~g} \mathrm{~kg}^{-1}\right)$ & 2.1 & nd & nd & nd & nd & nd \\
\hline $\mathrm{C} / \mathrm{N}$ & 7.0 & nd & nd & nd & nd & nd \\
\hline \multicolumn{7}{|l|}{ Exchangeable bases $\left(\mathrm{cmol}^{(+)} \mathrm{kg}^{-1}\right)$} \\
\hline $\mathrm{Ca}+\mathrm{Mg}^{\circ}$ & 34.7 & 38.0 & 33.1 & 24.1 & 23.0 & nd \\
\hline $\mathrm{Na}$ & 0.49 & 0.80 & 0.55 & 0.54 & 0.45 & nd \\
\hline $\mathrm{K}$ & 0.49 & 0.58 & 0.45 & 0.35 & 0.30 & nd \\
\hline C.E.C. $\left(\mathrm{BaCl}_{2}\right)\left(\mathrm{cmol}^{(+)} \mathrm{kg}^{-1}\right)$ & 35.7 & 39.4 & 34.1 & 25.0 & 23.7 & nd \\
\hline Base saturation (\%) & 100 & 100 & 100 & 100 & 100 & nd \\
\hline Available $\mathrm{P}$ as $\mathrm{P}_{2} \mathrm{O}_{5}\left(\mathrm{mg} \mathrm{kg}^{-1}\right)$ & 36.7 & 9.5 & 5.4 & 8.5 & 13.7 & nd \\
\hline
\end{tabular}

${ }^{\circ} \mathrm{Ca}+\mathrm{Mg}=$ C.E.C. $-\left(\mathrm{Na}^{+}+\mathrm{K}^{+}\right)$; nd: not determined

Table 3. Experimental scheme of the crop succession.

\begin{tabular}{lcccc} 
Plot-soils lyear & 2009 & 2010 & 2011 & \\
4-PF and CB & Wheat & Vicia faba minor & Wheat & Set aside \\
$5-\mathrm{PF}$ and $\mathrm{CB}$ & Set aside & Wheat & Vicia faba minor & Wheat \\
\hline $6-\mathrm{PF}$ and $\mathrm{CB}$ & Vicia faba minor & Wheat & Set aside & Wheat \\
$7-\mathrm{PF}$ and $\mathrm{CB}$ & Wheat & Set aside & Wheat & Vicia faba minor \\
\hline
\end{tabular}

$\mathrm{CB}$, Casabianca; PF, Piedifiume.

Table 4. Particle size characteristics of the four plots for each type of soil.

\begin{tabular}{lccccc} 
Soil & Plot & Depth $(\mathrm{cm})$ & Sand (\%) & Silt (\%) & Clay (\%) \\
PF & 4 & $0-10$ & 34.5 & 47.6 & 17.8 \\
PF & 5 & $0-10$ & 35.8 & 45.5 & 18.7 \\
\hline PF & 6 & $0-10$ & 40.7 & 43.3 & 16.0 \\
PF & 7 & $0-10$ & 37.6 & 44.9 & 17.5 \\
\hline CB & 4 & $0-10$ & 6.5 & 48.7 & 44.8 \\
CB & 5 & $0-10$ & 6.2 & 48.8 & 45.0 \\
\hline CB & 6 & $0-10$ & 3.8 & 53.0 & 43.1 \\
CB & 7 & $0-10$ & 8.3 & 52.3 & 39.4 \\
\hline
\end{tabular}

$\mathrm{CB}$, Casabianca; PF, Piedifiume.
Table 5. $\mathrm{pH}$, measured in both water and $\mathrm{KCl} 1 \mathrm{~N}$, of the four plots for each soil type.

\begin{tabular}{lcccc} 
Soil & Plot & Depth (cm) & pH H20 & pH KCl \\
PF & 4 & $0-10$ & 7.59 & 7.29 \\
PF & 5 & $0-10$ & 7.61 & 7.29 \\
\hline PF & 6 & $0-10$ & 7.63 & 7.28 \\
PF & 7 & $0-10$ & 7.58 & 7.30 \\
\hline CB & 4 & $0-10$ & 7.88 & 7.28 \\
CB & 5 & $0-10$ & 7.75 & 7.30 \\
\hline CB & 6 & $0-10$ & 7.75 & 7.30 \\
CB & 7 & $0-10$ & 7.80 & 7.37 \\
\hline
\end{tabular}

$\mathrm{CB}$, Casabianca; $\mathrm{PF}$, Piedifiume. 
Table 6. Organic carbon content and bulk density after a time interval of two agricultural years.

\begin{tabular}{|c|c|c|c|c|c|c|c|}
\hline \multirow[t]{2}{*}{ Soil } & \multirow[t]{2}{*}{ Plot } & \multirow{2}{*}{$\begin{array}{l}\text { Crop succession } \\
(\mathrm{cm})\end{array}$} & \multirow[t]{2}{*}{ Depth } & \multicolumn{2}{|c|}{ Organic carbon $\left(\mathrm{g} \mathrm{kg}^{-1}\right)$} & \multicolumn{2}{|c|}{ Bulk density $\left(\mathrm{g} \mathrm{cm}^{-3}\right)$} \\
\hline & & & & 2009 & 2010 & 2009 & 2010 \\
\hline $\mathrm{PF}$ & 4 & Wheat-Vicia faba minor & $0-10$ & 9.7 & 10.4 & 1.45 & $1 ., 40$ \\
\hline PF & 5 & Set aside-wheat & $0-10$ & 9.5 & 10.1 & 1.47 & 1.53 \\
\hline $\mathrm{PF}$ & 6 & Vicia faba minor-wheat & $0-10$ & 10.6 & 10.5 & 1.46 & 1.56 \\
\hline PF & 7 & Wheat-set aside & $0-10$ & 10.3 & 9.9 & 1.49 & 1.59 \\
\hline CB & 4 & Wheat-Vicia faba minor & $0-10$ & 17.1 & 18.4 & 1.25 & 1.16 \\
\hline $\mathrm{CB}$ & 5 & Set aside-wheat & $0-10$ & 17.7 & 16.1 & 1.37 & 1.31 \\
\hline CB & 6 & Vicia faba minor-wheat & $0-10$ & 16.8 & 14.7 & 1.27 & 1.38 \\
\hline CB & 7 & Wheat-set aside & $0-10$ & 15.3 & 11.2 & 1.31 & 1.41 \\
\hline
\end{tabular}

$\mathrm{CB}$, Casabianca; $\mathrm{PF}$, Piedifiume.

Table 7. BSQ $\mathrm{ar}_{\mathrm{ar}}$ and other biological indices calculated in the experiment. Types of soil management: A (no set-aside), B (mulching grass and then set aside), $C$ (ploughed field with green manure and then set aside).

\begin{tabular}{|c|c|c|c|c|c|c|c|}
\hline & & EMI & & & & $\mathbf{N}$ & \\
\hline & A & B & $\mathrm{C}$ & & A & B & C \\
\hline Acari & 20 & 20 & 20 & & 499 & 1354 & 243 \\
\hline Arachnids & - & - & 1 & & - & - & 1 \\
\hline Pseudoscorpion & 20 & - & - & & 1 & - & \\
\hline Opiliones & - & - & 10 & & - & - & 1 \\
\hline Isopoda & 10 & - & - & & 3 & - & - \\
\hline Symphyla & 20 & 20 & 20 & & 2 & 9 & 2 \\
\hline Diplopoda & 5 & - & 20 & & 2 & - & 1 \\
\hline Pauropoda & 20 & 20 & 20 & & 9 & 4 & 6 \\
\hline Collembola & 20 & 20 & 20 & & 220 & 353 & 18 \\
\hline Rhynchota & 1 & 1 & - & & 8 & 11 & - \\
\hline Diplura & 20 & 20 & 20 & & 2 & 1 & 7 \\
\hline Thysanoptera & 1 & 1 & - & & 1 & 1 & - \\
\hline Protura & - & 20 & - & & - & 70 & - \\
\hline Coleoptera & 10 & 6 & 1 & & 1 & 2 & 2 \\
\hline Hymenoptera & 1 & 5 & - & & 1 & 78 & - \\
\hline Diptera larvae & - & 10 & 10 & & - & 2 & 3 \\
\hline Other holometabolous insect larvae & - & 10 & 10 & & 1 & 4 & 7 \\
\hline Total BSQ & 148 & 153 & 152 & Total $n$ & 750 & 1889 & 291 \\
\hline Biological class & $V$ & $V$ & $V$ & Margalef index & 1.662 & 1.458 & 1.763 \\
\hline BF n & 12 & 12 & 11 & Shannon index & 0.846 & 0.910 & 0.756 \\
\hline
\end{tabular}

EMI, eco-morphological index; BF, biological forms; $\mathrm{N}$, abundance of arthropods.

decrease of bulk density is quite surely due to the tillage of soil by disk harrow associated to the burial of Vicia faba plants.

\section{CRA-ABP Experimental farm of Fagna, Scarperia}

Table 7 summarizes the composition of edaphic community, biodiversity indices and $\mathrm{BSQ}_{\mathrm{ar}}$ index.

$\mathrm{BSQ}_{\mathrm{ar}}$ indices are relatively high and equivalent to those obtained in semi-natural and natural areas. Many eu-edaphic biological forms were found; according to biological classification of soils with the $\mathrm{BSQ}_{\mathrm{ar}}$ index, each of three investigated areas at Fagna was classified at V level (high quality) without significant differences among them (see Figure 4).

Significance in abundance $(\mathrm{N})$ of microarthropods was among fields $A, B$ and $C$, especially concerning Acari: they were more abundant in the mulching field. In this case, edaphic environment seemed not disturbed by mulching treatment, which probably increased the availability of organic matter after the grass cut.
By literature on set-aside management, not all authors agree with the importance of permanence of spontaneous vegetation cover and suggested different control methods as an alternative to mowing or mulching. Some Authors suggest burying/replacement with other cover crops or weed control with synthetic or naturally derived products. Furthermore, the period of mulching or mowing, and the number of remedial measures highly depend on botanic species composition, geographic location and annual climate. The $\mathrm{BSQ}_{\mathrm{ar}}$ index generally shows greatest values in forest environments (120-200), where stability of the soil biota is high. In crops, values are usually less than 100 , while, in degraded or pioneer soils below 50. Studies conducted by Menta et al. (2008) showed that managements with permanent pasture and alfalfa result in $\mathrm{BSQ}_{\mathrm{ar}}$ values generally higher than those found in beet and maize crops, where $\mathrm{BSQ}_{\mathrm{ar}}$ index values are usually less than 100 .

In this case study, the $\mathrm{BSQ}_{\mathrm{ar}}$ indices obtained were high and did not differ from forest soils with high density of eu-edaphic species of arthropod community. The community composition of arthropods was 
depending on the management of the plant community.

The compliance with the standard 4.2 (maintenance of grass cover throughout the year on set aside) increased soil biological quality compared with ploughed soil. The abundance of soil fauna was higher in set aside fields with mulching treatment than in abandoned field.

Quality soil assessment through the $\mathrm{BSQ}_{\mathrm{ar}}$ index can be considered an effective method of monitoring, especially in economic terms. However, this index is recent and needs to be widely screened under different conditions.

\section{References}

Agronomica, 1995. Le tecniche di coltivazione delle principali colture agroindustriali. Edagricole, Bologna, Italy.

Aspetti G.P., Boccelli R., Ampollini D., Del Re Attilio A.M., Capri E., 2010. Assessment of soil-quality index based on microarthropods in corn cultivation in Northern Italy. Ecol. Indic. 10:129-135.

Ball B.C., O'Sullivan M.F., 1982. Soil strength and crop emergence in direct drilled and ploughed cereal seedbeds in seven field experiments. J. Soil Sci. 33:609-622.

Bazzoffi P., 2011. Effectiveness of the GAEC standard of cross compliance Management of set aside on soil erosion control. Ital. J. Agron. Special Issue of the Environmental effectiveness of GAEC Cross-compliance Standards implemented in Italy (in press).

Berti A., Sattin M., 1993. Gestione della vegetazione spontanea nei terreni a set-aside. pp 9-34 in Atti IX Convegno SILM, Bari, Italy.

Biaggini M., 2005. Diversità animale e agro-ambiente: analisi della fauna ad artropodi e "micro-vertebrati" e valutazione della qualità biologica del suolo in un centro sperimentale della Valdera. Degree Diss., Università degli Studi di Firenze, Italy.

Biaggini M., Consorti R., Dapporto L., Dellacasa M., Paggetti E., Corti C., 2007. The taxonomic level order as a possible tool for rapid assessment of Arthropod diversity in agricultural landscapes. Agr. Ecosyst. Environ. 122:183-191.

Cavazza L., Patruno A., Ardizzoni E., 1986. Influenza della lavorazione su alcune proprietà fisiche del terreno. Riv. Agron. 20:184-203.

Covarelli G., 1997. Gestione della flora spontanea nei terreni a setaside. Agricoltura Ricerca 69:31-38.

Covarelli G., Russo F., 1993. Le diverse possibilità di gestione agronomica dei terreni a set aside. Quaderno PANDA n. 3, parte seconda.

D’Avino L., 2002. Esposizione del metodo di Vittorio Parisi per la valutazione della Qualità Biologica del Suolo (QBS) e proposta di standardizzazione delle procedure. Museo di Storia Naturale dell'Università di Parma, CD ROM, Parma.

Eckert D.J.,1984. Tillage system planting date interactions in corn production. Agron. J. 76:580-582.

Evans A., Curtoys J., Kew J., Lea A., Rayment M., 1997. Set-aside: conservation by accident... and design? RSPB Conservation Review 11:59-66.

Ferrazzi P., Berger F., Verti F., 2007. Biomonitoraggio della qualità dei suoli nei comuni di Agenda 21 Laghi. IV Forum di Agenda 21 Laghi, 16 giugno 2007, Di.Va.P.R.A., Settore Entomologia e Zoologia Applicate all'Ambiente "Carlo Vidano". University of Torino, Italy.

Gardi C, Tomaselli M, Parisi V, Petraglia A, Santini C., 2002. Soil quality indicators and biodiversity in northern Italian permanent grasslands. Eur. J. Soil Biol. 38:103-110.

Gillings S., Henderson I. G., Morris A. J. and Vickery J. A., 2010. Assessing the implications of the loss of set aside for farmland birds. Ibis 152:713-723.

Henderson I.G., Cooper J., Fuller R.J., Vickery J.A., 2000. The relative abundance of birds on set-aside and neighbouring fields in summer. J. Appl. Ecol. 37:335-347.
Margalef R., 1994. Dynamic aspects of diversity. J. Veg. Sci. 5:451-456. Mazzoncini M., Canali S., Giovannetti M., Castagnoli M., Tittarelli F., Antichi D., Nannelli R., Cristani C., Barberi P., 2010. Comparison of organic and conventional stockless arable systems: A multidisciplinary approach to soil quality evaluation. Appl. Soil Ecol. 44:124-132.

Menta C., Leoni A., Bardini M., Gardi C., Gatti F., 2008. Nematode and microarthropod communities: comparative use of soil quality bioindicators in covered dump and natural soils. Environ. Bioind. 3:35-46.

Ministero delle Politiche Agricole, Alimentari e Forestali, 1997. Osservatorio Nazionale Pedologico e per la Qualità del Suolo. Metodi di Analisi Fisica del Suolo. Franco Angeli ed., Milano, Italy.

Ministero delle Politiche Agricole, Alimentari e Forestali, 2000. Osservatorio Nazionale Pedologico e per la Qualità del Suolo. Metodi di Analisi Chimica del Suolo. Franco Angeli ed., Milano, Italy.

Montemurro P., Marzi V., Sarli G., 1997. Primi risultati di una sperimentazione sulla gestione della vegetazione spontanea nei terreni a set aside in un ambiente del Sud-Italia. Agricoltura Ricerca169:53-58.

Pagliai M., Vignozzi N., Pellegrini S., 2004. Soil structure and the effect of management practices. Soil Till. Res. 79:131-143.

Paradisi U., Baldoni G., Viggiani P., Catione P., 1997. Gestione della copertura vegetale in un terreno assoggettato a set-aside. Agricoltura Ricerca169:13-22.

Pardini A., Piemontese S., Staglianò N., Talamucci P., 1994. Influenza del pascolo combinato in bosco e in bande parafuoco inerbite sull'offerta e sull'utilizzazione della fitomassa erbacea e arbustiva. Riv. Agron. 28:57-63.

Parisi V., 1974. Biologia e ecologia del suolo: tecniche di ricerca. Boringhieri Ed., Torino, Italy.

Parisi V., 2001. La qualità biologica del suolo. Un metodo basato sui microartropodi. Acta Naturalia 37:97-106.

Parisi V., Menta C., Gardi C., Jacomini C., Mozzanica E., 2005. Microarthropod communities as a tool to assess soil quality and biodiversity: a new approach in Italy. Agr. Ecosyst. Environ. 105: 323-333.

Purvis C.E., 1990. Allelopathy: a new direction in weed control. Plant Protection Quarterly 5:55-59.

Rodriguez A., 1993. Jachère spontanée: halte aux mauvaises herbes. Cultivar 353:65-67.

Shannon C.E., Weaver W.,1949. The Mathematical Theory of Communication. University of Illinois Press, Urbana, IL, USA.

Silcock P., Lovegrove C., 2007. Retaining the Environmental Benefits of Set aside - A Policy Options Paper. Report for LUPG, Cumulus Consultants Ltd. Available from: http://www.lupg.org.uk/ pdf/pubs_Retainingenvbenefitsofsetaside07.pdf

Simpson E.H., 1949. Measurement of diversity. Nature 163:688.

Soil Survey Staff, 2003. Keys to Soil Taxonomy, 9th Ed. US Department of Agriculture Soil Conservation Service. Pocahontas Press, Inc., Blacksburg, VA, USA.

Swanton C. J., Clements D. R., Derksen D. A., 1993. Weed succession under conservation tillage: a hierarchical framework for research and management. Weed Technol. 7:286-297.

Tabaglio V., Gavazzi C., Menta C., 2009. Physico-chemical indicators and microarthropod communities as influenced by no-till, conventional tillage and nitrogen fertilisation after four years of continuous maize. Soil Till. Res. 105 135-142.

Van Buskirk J., Willi Y., 2004. Enhancement of Farmland Biodiversity within Set aside Land. Conserv. Biol. 18:987-994.

Whelan J., 1985. Seasonal fluctuations and vertical distribution of the acarine fauna of three grassland sites. Pedobiologia 26:191-201. 